\title{
Trinexapac-Ethyl Causes Stimulatory Effect on the Initial Growth of Eucalyptus urograndis Clones
}

\author{
Allan Lopes Bacha ${ }^{1}$, Pedro de F. R. Barbosa Martins ${ }^{1}$, Willians César Carrega ${ }^{1}$, Pedro Luis da C. A. Alves ${ }^{1,2}$ \\ $\&$ Rinaldo Cesar de Paula ${ }^{3}$ \\ ${ }^{1}$ Weed Sciences Laboratory (LAPDA), Sao Paulo State University, UNESP/FCAV, Jaboticabal, SP, Brazil \\ ${ }^{2}$ Department of Biology Applied to Agriculture, Sao Paulo State University, UNESP/FCAV, Jaboticabal, SP, \\ Brazil \\ ${ }^{3}$ Department of Plant Production, Sao Paulo State University, UNESP/FCAV, Jaboticabal, SP, Brazil \\ Correspondence: Allan Lopes Bacha, Weed Sciences Laboratory (LAPDA), Sao Paulo State University, \\ UNESP/FCAV, Via de Acesso Prof. Paulo Donato Castellane s/n, CEP 14884-900, Jaboticabal, SP, Brazil. Tel: \\ 55-16-3206-2620. E-mail: allan_lb@hotmail.com
}

Received: July 12, 2017

doi:10.5539/jas.v9n10p189
Accepted: August 12, $2017 \quad$ Online Published: September 15, 2017

URL: https://doi.org/10.5539/jas.v9n10p189

\begin{abstract}
Eucalyptus plants are sensitive to stress factors in the initial growth phase. The plant growth regulator trinexapac-ethyl can provide gains to eucalyptus plants, a phenomenon known as hormesis. Thus, the aim of this work was to evaluate the effect of trinexapac-ethyl on the initial growth of two Eucalyptus urograndis clones (Clone $1=\mathrm{I}-144$ and Clone $2=1407$ ). The experiment was performed during 90 days after planting (DAP) of eucalyptus, in $100 \mathrm{~L}$ pots, with a randomized complete block design. The treatments were arranged in a $2 \times 3$ factorial scheme, with two eucalyptus clones and three trinexapac-ethyl doses $\left(0,30\right.$ and $60 \mathrm{~g}$ i.a. ha $\left.{ }^{-1}\right)$, with four replications. Fortnightly, plants height and stem diameter were evaluated. At 90 DAP, the leaf area and plants dry matter (DM) were evaluated. Clone 1 obtained leaf area and total DM 53\% and 58\% larger than Clone 2, respectively. The higher dose of trinexapac-ethyl provided mean gains of $30 \%$ in stem DM and total DM in Clone 1. For Clone 2, both doses of the product caused mean gains of $70 \%$ in stem DM, leaf DM and total DM. In conclusion, trinexapac-ethyl has a positive effect on the initial growth of $E$. urograndis, Clones I-144 and 1407. Clone I-144 showed higher growth than Clone 1407, regardless trinexapac-ethyl application. However, the Clone 1407 obtained more expressive gains with the application of trinexapac-ethyl, compared to Clone I-144.
\end{abstract}

Keywords: hormesis, hormetic effect, plant growth regulator, ripener, subdose

\section{Introduction}

The eucalyptus crop is the most important for the Brazilian forestry sector, which has considerable relevance in the country's economy, accounting for $1.2 \%$ of national GDP (Indústria Brasileira de Árvores [IBÁ], 2016). In more than 5.6 million hectares planted, eucalyptus plantations in Brazil have the highest productivity in the world, with $36 \mathrm{~m}^{3} \mathrm{ha}^{-1}$ year ${ }^{-1}$ in 2015 , being the product destined for the production of paper, pulp, wood, among others (Ibá, 2016).

The initial growth period of eucalyptus, which includes the first year after crop establishment, is the period in which plants are most susceptible to interference imposed by stress factors, which may directly reflect in the productivity (Nambiar \& Sands, 1993; Garau, Lemcoff, Ghersa, \& Beadle, 2008). Thus, studies looking for management options that provide gains to eucalyptus during this critical period are important, and the hormetic effect may be a viable alternative.

The hormetic effect is characterized as a stimulatory response resulting from the application of a chemical product that would be toxic in high quantities (Calabrese \& Baldwin, 2002; Belz \& Duke, 2014). This phenomenon has already been observed for several plant species and products, including trinexapac-ethyl in eucalyptus plants (Velini et al., 2008; Pereira, Nepomuceno, Pires, Parreira, \& Alves, 2013; Pires, Pereira, Nepomuceno, \& Alves, 2013; Correia \& Villela, 2015).

However, the occurrence of the hormetic phenomenon depends on several factors, such as: stage of development of the plant; final evaluation point; environmental conditions; and cultivar or clone used (Belz \& Duke, 2014). 
Thus, due to the existence of several clones used in commercial eucalyptus plantations, it is important to evaluate how the different clones respond to the trinexapac-ethyl, and the possible hormetic effect caused by this product, since these results can provide knowledge to producers and researchers and may guide future studies in this sense.

Trinexapac-ethyl is a plant growth regulator recommended for application in sugarcane cultivation, aiming to accelerate the plant maturation processes (Nascimento et al., 2009; Moddus, 2017). This compound, commonly known as a ripener, mimics the chemical structure of 2-oxogluterate acid and is an acylcyclohexanedione that interferes with the final stages of gibberellin biosynthesis (Rademacher, 2000). At the cellular level, trinexapac-ethyl acts reducing cell elongation of some monocotyledonous species, such as rice and wheat (Nascimento et al., 2009). Due to the inhibition of the 3-hydroxylase enzyme (Nakayama, Kamiya, Kobayashi, Abe, \& Sakurai, 1990) the level of the active gibberellic acid $\left(\mathrm{GA}_{1}\right)$ is significantly reduced, increasing its immediate biosynthetic precursor $\mathrm{GA}_{20}$ (Adams, Kerber, Pfister, \& Weiler, 1992). The authors also emphasized that this response is related to the competition between the trinexapac-ethyl molecule and 2-oxogluterate by the cosubstrate $\mathrm{Fe}^{+2}$ /ascorbate-dependent dioxygenase. However, low doses of this compound do not negatively affect the initial growth of eucalyptus (Pires et al., 2013; Correia \& Villela, 2015).

With the hypothesis that different eucalyptus clones respond differently to trinexapac-ethyl, the present study aimed to evaluate the effect of trinexapac-ethyl on the initial growth of two Eucalyptus urograndis clones (Clone I-144 and Clone 1407).

\section{Materials and Methods}

\subsection{Experimental Area and Plant Materials}

The experiment was conducted in an open and semi-controlled area, from April to July 2016, in the municipality of Jaboticabal-SP, Brazil (altitude of $590 \mathrm{~m}$ and geographic coordinates of $21^{\circ} 15^{\prime} 17^{\prime \prime} \mathrm{S}$ and $48^{\circ} 19^{\prime} 20^{\prime \prime} \mathrm{W}$ ). During the experimental period, the average air temperature was $20.3{ }^{\circ} \mathrm{C}$ (maximum of $28.2^{\circ} \mathrm{C}$ and minimum of $14.6^{\circ} \mathrm{C}$ ), with relative humidity of $69.2 \%$ and insolation of 242 hours per month (meteorological data in Table $1)$.

Table 1. Monthly meteorological data of Jaboticabal-SP region, Brazil, 2016

\begin{tabular}{lllllllll}
\hline Month & Pressure $(\mathrm{hPa})$ & $\operatorname{Tmax}\left({ }^{\circ} \mathrm{C}\right)$ & $\operatorname{Tmin}\left({ }^{\circ} \mathrm{C}\right)$ & $\operatorname{Tave}\left({ }^{\circ} \mathrm{C}\right)$ & $\mathrm{RH}(\%)$ & Precipitation $(\mathrm{mm})$ & $\mathrm{NRD}$ & Insolation $(\mathrm{h})$ \\
\hline Apr & 944.8 & 31.5 & 18.0 & 24.0 & 65.6 & 9.1 & 2 & 267.6 \\
May & 947.1 & 27.4 & 15.0 & 20.1 & 74.9 & 118.2 & 9 & 203.1 \\
Jun & 948.5 & 25.7 & 12.9 & 18.1 & 75.3 & 115.8 & 8 & 220.1 \\
Jul & 947.4 & 28.5 & 12.6 & 19.3 & 61.2 & 0.0 & 0 & 277.7 \\
\hline
\end{tabular}

Note. Pressure: atmospheric pressure; Tmax: average maximum temperature; Tmin: average minimum temperature; Tave: average temperature; RH: relative humidity of air; NRD: number of rainy days.

The experiment was performed for 90 days after planting (DAP) of eucalyptus seedlings in $100 \mathrm{~L}$ pots $(0.62 \times$ $0.62 \times 0.26 \mathrm{~m}$ ) previously filled with Dark Red Oxisol (Table 2).

Table 2. Chemical analysis of used substratum on experimental parcels. Jaboticabal-SP, 2016

\begin{tabular}{|c|c|c|c|c|c|c|c|c|c|}
\hline $\mathrm{pH}_{\mathrm{CaCl} 2}$ & M.O. & P resin & $\mathrm{K}$ & $\mathrm{Ca}$ & $\mathrm{Mg}$ & $\mathrm{H}+\mathrm{Al}$ & SB & $\mathrm{T}$ & $\mathrm{V}$ \\
\hline & $--\mathrm{g} \mathrm{dm}^{-3}--$ & -- $\mathrm{mg} \mathrm{dm}^{-3}$-- & --- & --- & ----- & $\mathrm{dm}^{-3}-$ & 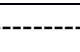 & ---- & -- \% -- \\
\hline 6.0 & 23 & 102 & 1.4 & 46 & 10 & 20 & 57.3 & 77.3 & 74 \\
\hline
\end{tabular}

Commercial seedlings of two E. urograndis clones were used. Clone 1 (Clone I-144) seedlings had an average of 100 days of age, $45 \mathrm{~cm}$ of height, $3.67 \mathrm{~mm}$ of stem diameter and 11 leaves. The seedlings of Clone 2 (Clone 1407) had an average of 100 days of age, $36 \mathrm{~cm}$ of height, $3.62 \mathrm{~mm}$ of stem diameter and 15 leaves.

\subsection{Trinexapac-Ethyl Application, Treatments and Experimental Design}

Prior to planting, the eucalyptus seedlings of both clones, still conditioned in $50 \mathrm{~mL}$ tubes, were sprayed with trinexapac-ethyl (Moddus ${ }^{\circledR}$ ) at the doses of 30 and $60 \mathrm{~g}^{\text {i.a. }}$ ha $^{-1}$ (10 and $20 \%$ of the recommended commercial dose for sugarcane, respectively). For this, we used a costal sprayer with constant pressure $\left(\mathrm{CO}_{2}\right)$ equipped with 
a double rod TT 110.02 and adjusted to spray a tank volume of $200 \mathrm{~L} \mathrm{ha}^{-1}$. At the time of application, which occurred in a spray room, the air temperature was $27.1{ }^{\circ} \mathrm{C}$ with relative humidity of $62 \%$. Twenty-four hours after trinexapac-ethyl application, all seedlings were planted in the pots.

A randomized complete block design was used, and the treatments arranged in a $2 \times 3$ factorial scheme, which means two eucalyptus clones (Clone $1=\mathrm{I}-144$ and Clone $2=1407$ ) and three doses of trinexapac-ethyl $[0 \%$ (control without application), $10 \%$ and $20 \%$ of the commercial dose] with four replicates.

Each pot was considered an experimental unit and all seedlings were irrigated daily until field capacity. At 45 DAP, a fertilization of $200 \mathrm{~kg} \mathrm{ha}^{-1}$ of urea was carried out.

\subsection{Assessed Variables and Statistical Analysis}

Fortnightly, plants height and stem diameter were evaluated until the 90 DAP. At the end of the experimental period, the plants were cut at the base level and its leaves were detached for leaf area determination (LiCor, mod. LI $3100 \mathrm{~A})$. Then, leaves and stems were taken into forced air circulation oven $\left(70^{\circ} \mathrm{C}\right)$, for 96 hours, to determine the dry matter mass in a precision electronic scale.

The data of leaf area, dry matter, height and stem diameter at 90 DAP were submitted to analysis of variance (ANOVA) by the $\mathrm{F}$ test and the means compared by the Tukey test, at a 5\% probability level.

Separately for each clone, a regression analysis was performed according to a second-order polynomial model (Equation 1), with the data of eucalyptus height and stem diameter collected fortnightly (MicroCal Origin, v.8). The data of leaf area and dry matter were transformed to percentage, considering the control as $100 \%$, and expressed in bar graphs (MicroCal Origin, v.8).

\section{Results and Discussion}

$$
y=\text { Intercept }+B 1 \cdot x+B 2 \cdot x^{2}
$$

For Clone 1 (I-144) plants height, no positive effect of trinexapac-ethyl was observed until 75 DAP, however, in the last evaluation (90 DAP), the highest dose of the product provided an increase of $12.5 \%$ compared to the control (Figure 1-A). For stem diameter, both tested doses showed an average increase of $12 \%$ compared to the control at 90 DAP. Up to 75 DAP, there was no difference between treatments (Figure 1-B).

Compared to Clone 1, Clone 2 (1407) obtained an earlier response to trinexapac-ethyl, differing from the control 60 days after exposure to the product. In the final evaluation (90 DAP), the application of $20 \%$ dose of trinexapac-ethyl provided an increase in plants height of $9.6 \%$ compared to the plants that was not exposed to the ripener (Figure 2-A). The response of the stem diameter was even more expressive and could be perceived from 60 DAP on (Figure 2-B). It was also possible to observe that at 75 DAP, the values of the plants treated with both doses were similar to those of the control at 90 DAP. In the last evaluation, trinexapac-ethyl provided gains of $25 \%$ compared to control, evidencing that this characteristic was more sensitive to the product in comparison to the plants height (Figure 2-B).

The gains observed in plants exposed to trinexapac-ethyl are defined as hormesis, and are characterized as a stimulatory effect caused by the action of low doses of a chemical product that is toxic to plants when applied at high doses (Belz \& Duke, 2014). This effect has already been observed for forest species in previous works, including studies that used the plant growth regulator trinexapac-ethyl (Velini et al., 2008; Pires et al., 2013; Correia \& Villela, 2015).

In an experiment performed during 42 DAP, Pires et al. (2013) sprayed 20 g i.a. ha ${ }^{-1}$ of trinexapac-ethyl and found gains up to $13 \%$ in leaf dry matter and $19 \%$ in leaf area of E. urograndis seedlings. The authors also suggested that the ripener did not have a deleterious effect on the photosynthetic characteristics of eucalyptus. 
A)

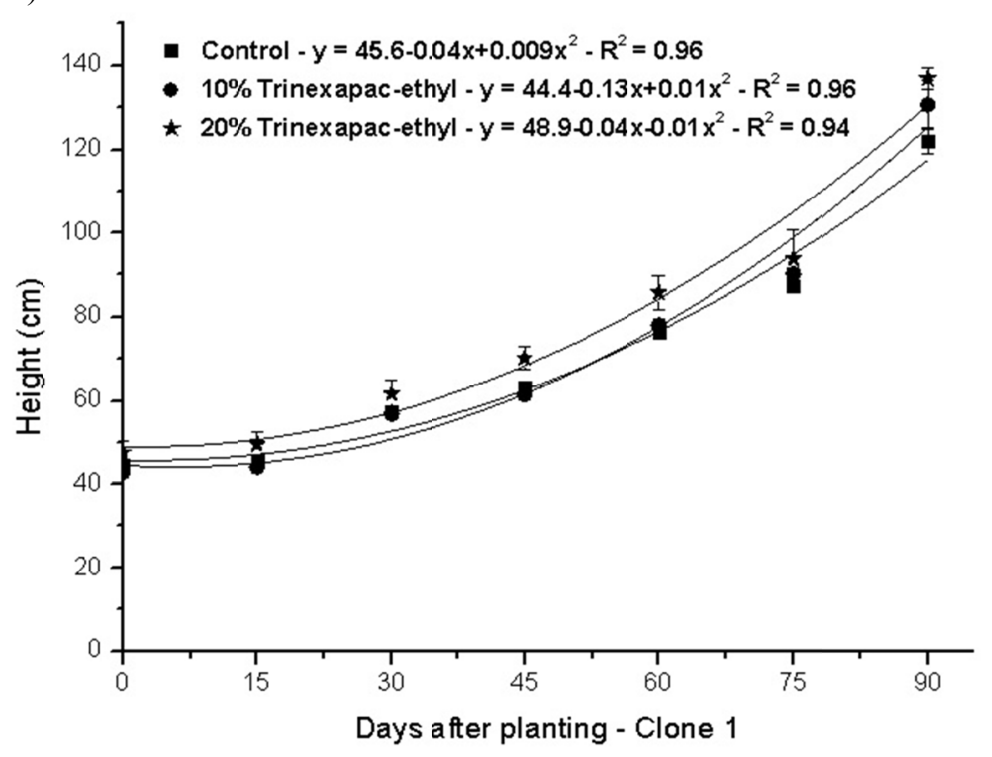

B)

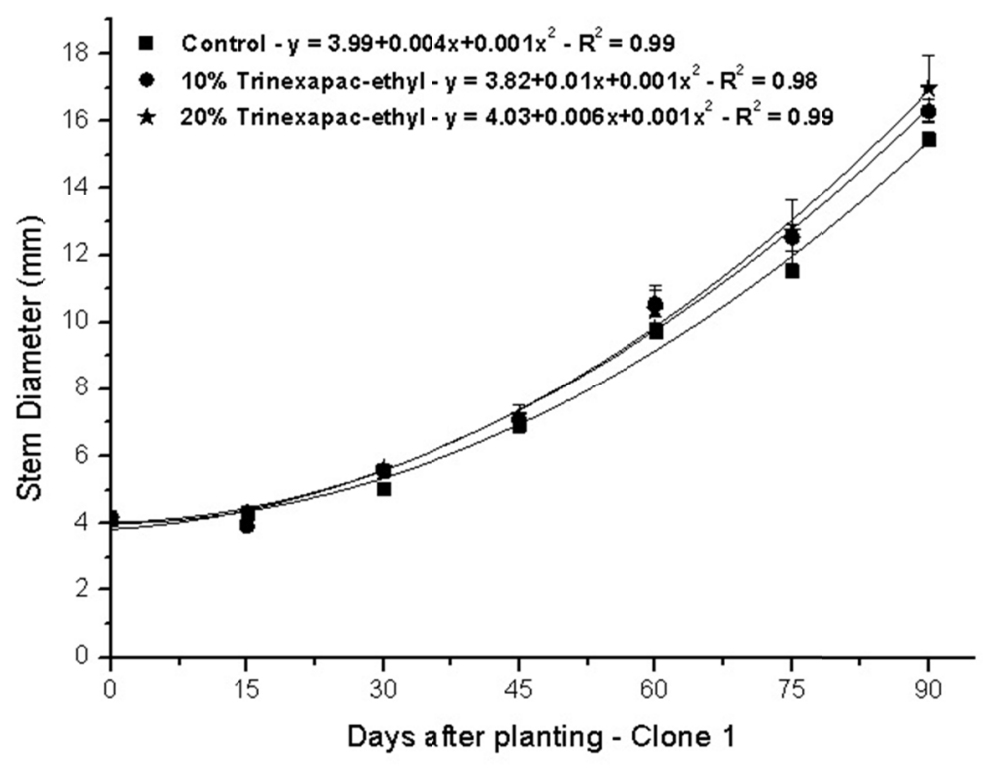

Figure 1. Plants height and stem diameter of Eucalyptus urograndis (Clone 1 = I-144) exposed to the application of $10 \%$ and $20 \%$ of trinexapac-ethyl 
A)

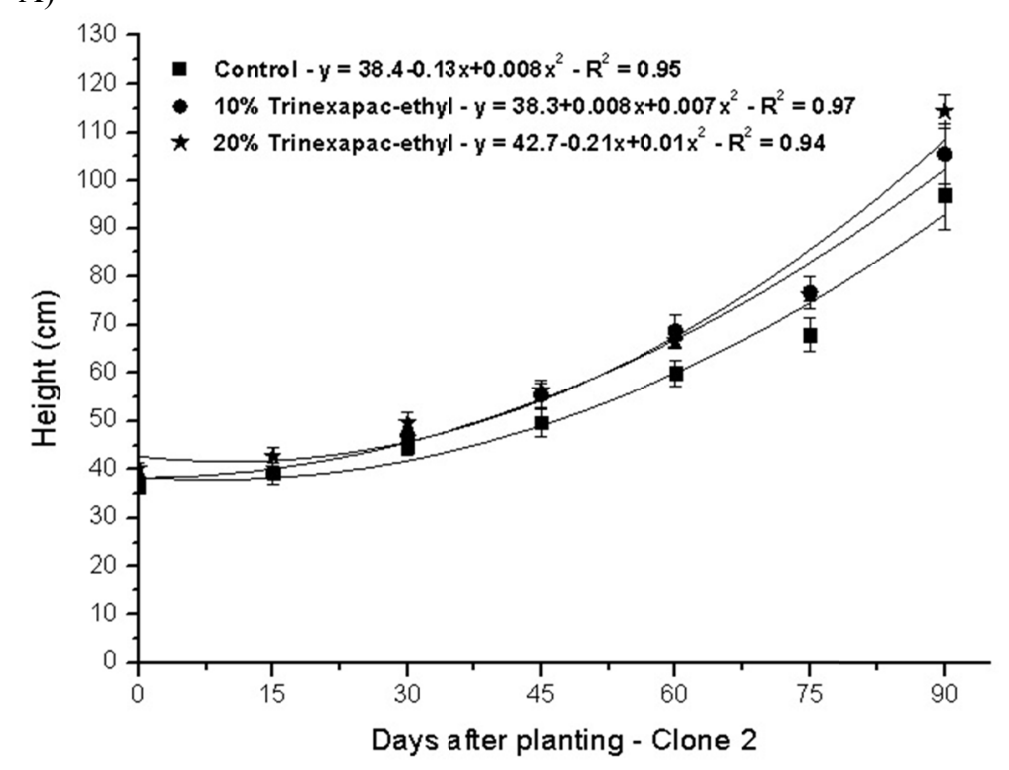

B)

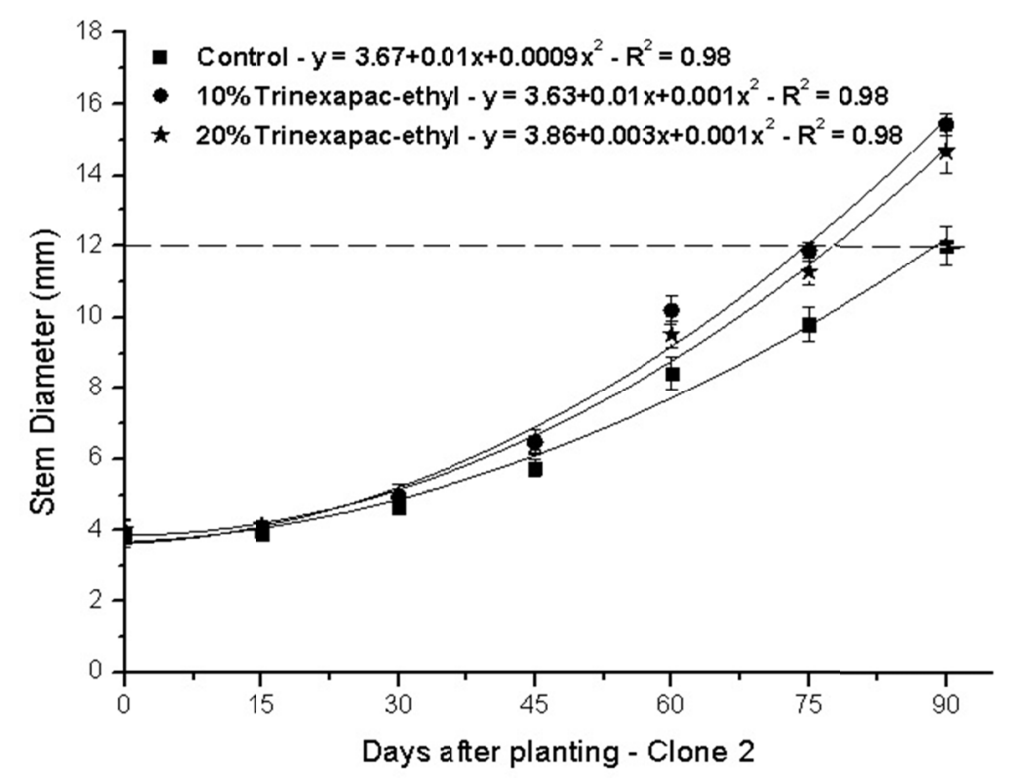

Figure 2. Plants height and stem diameter of Eucalyptus urograndis (Clone $2=1407$ ) exposed to the application of $10 \%$ and $20 \%$ of trinexapac-ethyl

Although Clone 2 responded earlier to trinexapac-ethyl, Clone 1 was the one that developed the most, reaching values up to $58 \%$ higher (for total dry matter) compared to Clone 2 . Clone 1 also had higher height (23\%), stem diameter $(15.7 \%)$, leaf area (53\%) and leaf dry matter (49.4\%) compared to Clone 2 (Table 3 ).

For trinexapac-ethyl, only the leaf area did not respond positively to the product, probably due to the variation of the results of the samples, which reflected in the values of the coefficient of variation (Table 3). All the other variables had a positive response to trinexapac-ethyl, with an average increase of $37.6 \%$ in dry matter of leaves and $36.8 \%$ in total dry matter (Table 3 ). 
Table 3. Comparison between Clone 1 (I-144) and Clone 2 (1407) of Eucalyptus urograndis submitted to the application of trinexapac-ethyl, for the variables plants height $(\mathrm{cm})$, stem diameter $(\mathrm{mm})$, stem dry matter (Stem DM-g), Leaf area $\left(\mathrm{cm}^{2}\right)$, leaf dry matter (Leaf DM-g) and total dry matter (Total DM-g)

\begin{tabular}{lllllll}
\hline Treatments & Height & Diameter & Stem DM & Leaf Area & Leaf DM & Total DM \\
\hline Clone 1 & $129.9 \mathrm{~A}$ & $16.2 \mathrm{~A}$ & 62.2 & $6238.1 \mathrm{~A}$ & $66.8 \mathrm{~A}$ & $129.1 \mathrm{~A}$ \\
Clone 2 & $105.6 \mathrm{~B}$ & $14.0 \mathrm{~B}$ & 36.8 & $4079.3 \mathrm{~B}$ & $44.7 \mathrm{~B}$ & $81.6 \mathrm{~B}$ \\
\hline $0 \%$ Trinexapac-ethyl & $109.6 \mathrm{~B}$ & $13.7 \mathrm{~B}$ & 39.6 & $4263.3 \mathrm{~A}$ & $44.7 \mathrm{~B}$ & $84.4 \mathrm{~B}$ \\
$10 \%$ Trinexapac-ethyl & $118.1 \mathrm{AB}$ & $15.8 \mathrm{~A}$ & 51.8 & $5622.6 \mathrm{~A}$ & $60.7 \mathrm{~A}$ & $112.5 \mathrm{~A}$ \\
20\% Trinexapac-ethyl & $125.6 \mathrm{~A}$ & $15.8 \mathrm{~A}$ & 57.1 & $5590.2 \mathrm{~A}$ & $61.9 \mathrm{~A}$ & $119.1 \mathrm{~A}$ \\
\hline F (Clone) & $32.5^{* *}$ & $24.9^{* *}$ & $139.0^{* *}$ & $18.9^{* *}$ & $74.3^{* *}$ & $109.3^{* *}$ \\
F (Trinexapac-ethyl-TE) & $4.70^{*}$ & $9.97^{* *}$ & $22.9^{* *}$ & $3.27^{\text {ns }}$ & $18.8^{* *}$ & $21.9^{* *}$ \\
F (Clone $\times$ TE) & $0.03^{\text {ns }}$ & $2.84^{\text {ns }}$ & $4.28^{*}$ & $0.45^{\text {ns }}$ & $0.80^{\text {ns }}$ & $1.97^{\text {ns }}$ \\
CV (\%) & 8.86 & 7.14 & 10.6 & 23.5 & 11.2 & 10.5 \\
\hline
\end{tabular}

Note. Means followed by the same letter in the column do not differ from each other by the Tukey test at 5\% of probability. $*=$ Significant value at $5 \%$ of probability by the $\mathrm{F}$ test. $* *=$ significant value at $1 \%$ of probability by the $\mathrm{F}$ test. ${ }^{\mathrm{ns}}=$ value not significant at $5 \%$ of probability by the $\mathrm{F}$ test. $\mathrm{CV}=\mathrm{Coefficient}$ of variation.

For the stem dry matter, it was possible to observe that Clone 1 again obtained higher values compared to Clone 2 (Table 4). However, in Clone 1 , only plants that were treated with $20 \%$ trinexapac-ethyl differed significantly from the control, whereas in Clone 2 both doses of the product showed significant gains (Table 4).

The hormetic effect caused by the application of low-doses of chemicals depends on several intrinsic and extrinsic factors of plants (Belz \& Duke, 2014), such as: plant development stage (Carvalho, Alves, \& Duke, 2013); environmental conditions (Belz \& Cedergreen, 2010); the period between the exposure to the product and the final evaluation point (Cedergreen, Felby, Porter, \& Streibig, 2009); and the clone or cultivar used (McDonald, Morgan, \& Jackson, 2001). This justifies the difference between the results found for the clones, since different genetic materials tend to present different patterns of growth, and respond in different ways to the application of the same product. Thus, studies in this sense may provide important information for the selection of clones that take advantage of the positive effect provided by the application of trinexapac-ethyl.

Table 4. Interaction of the factors "clones" $\times$ "trinexapac-ethyl doses" for the variable stem dry matter of Eucalyptus urograndis. Clone 1 = I-144 and Clone $2=1407$

\begin{tabular}{llll}
\hline Treatments & Clone 1 & Clone 2 & F \\
\hline $0 \%$ Trinexapac-ethyl & $54,6 \mathrm{~B} \mathrm{a}$ & $24,7 \mathrm{~B} \mathrm{~b}$ & $64,1^{* *}$ \\
$10 \%$ Trinexapac-ethyl & $60,0 \mathrm{~B} \mathrm{a}$ & $43,5 \mathrm{~A} \mathrm{~b}$ & $19,5^{* *}$ \\
$20 \%$ Trinexapac-ethyl & $72,1 \mathrm{~A} \mathrm{a}$ & $42,2 \mathrm{~A} \mathrm{~b}$ & $63,9 *$ \\
\hline $\mathrm{F}$ & $11,4^{* *}$ & $15,8^{* *}$ & - \\
\hline
\end{tabular}

Note. Means followed by the same uppercase letter in the column, and lowercase in the row, do not differ from each other by the Tukey test at $5 \%$ of probability. $* *=$ significant value at $1 \%$ probability by the $\mathrm{F}$ test.

By analyzing separately the gains obtained for each clone, it was possible to observe that the higher dose of trinexapac-ethyl gave Clone 1 a $31 \%$ increase in stem dry matter, differing significantly from the control (Figure 3). For the variables leaf area and leaf dry matter, the product did not provided statistically significant gains compared to the control. However, for the total dry matter, there was an increase of approximately $30 \%$ in relation to the control for dose of $20 \%$ of trinexapac-ethyl (Figure 3). 


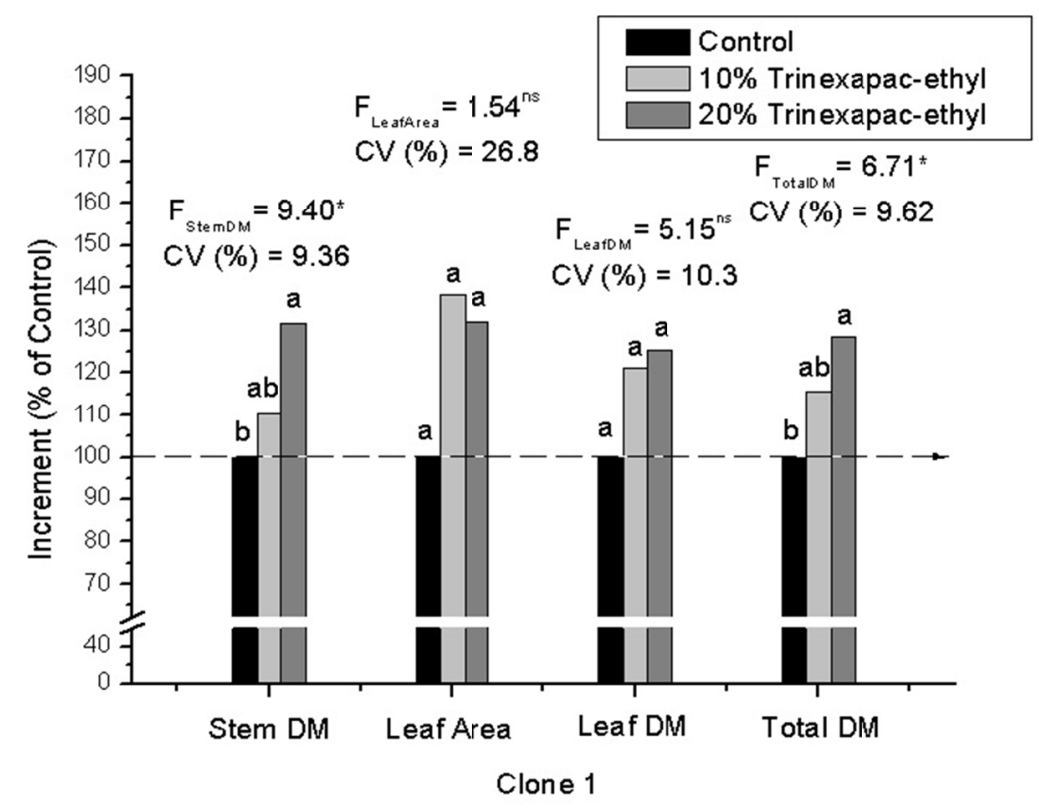

Figure 3. Effect of trinexapac-ethyl on stem dry matter (Stem DM), leaf area, leaf dry matter (Leaf DM) and total dry matter (Total DM) of Eucalyptus urograndis (Clone $1=\mathrm{I}-144)$ at 90 days after planting. Values expressed in increments compared to the control (in percentage)

Clone 2 presented more expressive responses to trinexapac-ethyl, in which only the leaf area did not differ statistically from the control (Figure 4). For the stem dry matter, both doses provided, on average, gains of $70 \%$ compared to the control. The same response pattern was observed for leaf dry matter and total dry matter, with mean gains of approximately $70 \%$ for both evaluated characteristics (Figure 4 ).

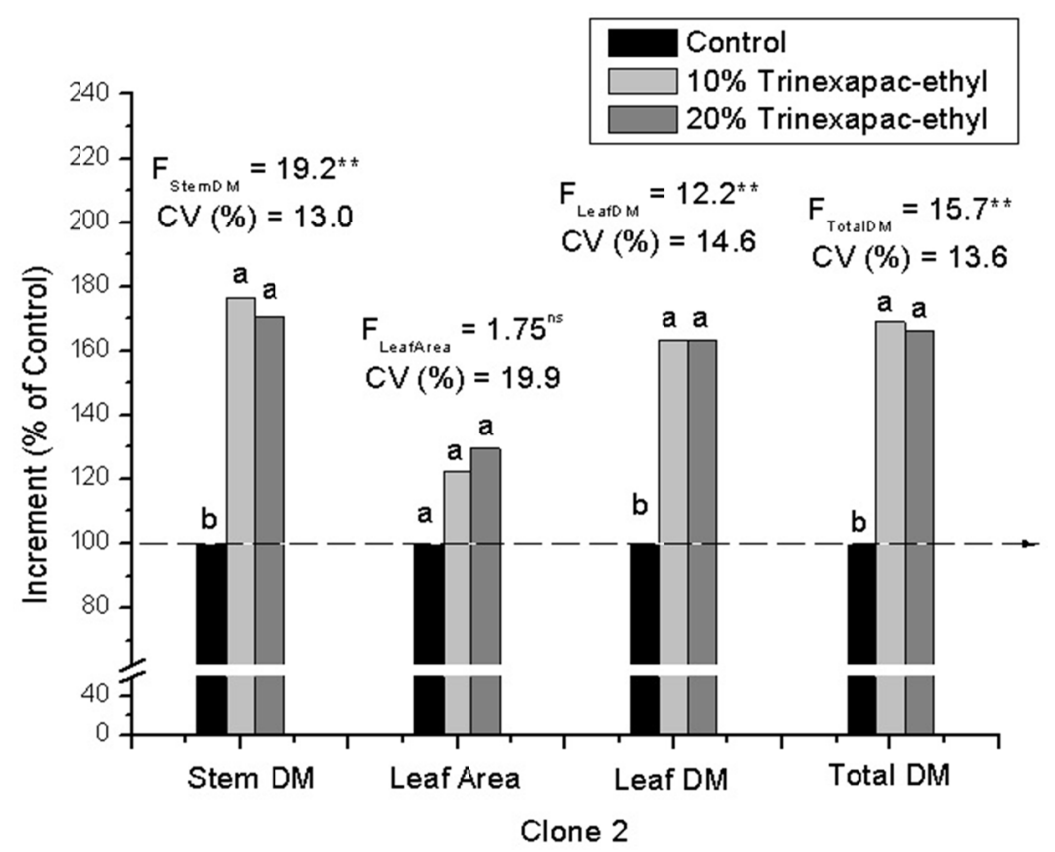

Figure 4. Effect of trinexapac-ethyl on stem dry matter (Stem DM), leaf area, leaf dry matter (Leaf DM) and total dry matter (Total DM) of Eucalyptus urograndis (Clone $2=1407$ ) at 90 days after planting. Values expressed in increments compared to the control (in percentage) 
These results show that Clone 2 presented proportionally more significant gains with the application of trinexapac-ethyl compared to Clone 1. Thus, it is possible to infer that Clone 2 is more sensitive to the product than Clone 1.

Correia and Villela (2015) also verified a positive effect of trinexapac-ethyl in eucalyptus plants with a completely established root system. The authors found a $29.2 \%$ increase in the crown diameter of the Clone GG-100 at 45 days after the application of $200 \mathrm{~g}$ i.a. $\mathrm{ha}^{-1}$ of the ripener. It should be noted that the plants were older at the time of product application, which occurred at 73 DAP. The difference in the gains observed between the studies is possibly related to the plant's age, since younger plants require lower doses, while older plants need higher doses of the same compound to the occurrence of hormesis (Belz \& Duke, 2014). This response can also be observed in the work of Velini et al. (2008). The authors found that the maximum hormetic response of Commelina benghalensis with two expanded leaves occurred at a dose five times lower than that used in plants with four expanded leaves.

In addition, for the hormetic effect to be significant in the production, it is important that the product application occurs at the correct time of the plant's development. For example, the application of low doses of glyphosate in barley at the two-leaf stage yielded no gains in productivity (Cedergreen, 2008). However, the application of this product at the grain filling stage provided gains of 12 to $15 \%$ in barley productivity (Cedergreen et al., 2009).

The trinexapac-ethyl plant growth regulator is an acylcyclohexanedione frequently used in monocotyledonous crops, because it causes a reduction in internodes' elongation, avoiding the lodging of these plants (Nascimento et al., 2009). Adams et al. (1992) emphasized that the mode of action of this ripener is related to the inactivation of the enzyme $\mathrm{GA}_{20} 3 \beta$-hydroxylase, in the production process of $\mathrm{GA}_{1}$ gibberellins. This inactivation occurs because trinexapac-ethyl competes with 2-oxogluterate for cosubstrate $\mathrm{Fe}^{+2}$ /ascorbate-dependent dioxygenase, causing an accumulation of $\mathrm{GA}_{20}$. Thus, there is a possibility that the unbalance in $\mathrm{GA}_{20} / \mathrm{GA}_{1}$ production is positively used by eucalyptus after the product's degradation, since low doses of this ripener have positive effect on eucalyptus, as observed in the present work and also verified by other authors (Pires et al., 2013; Correia \& Villela, 2015).

The hormetic effect caused by the application of trinexapac-ethyl, as well as the physiological processes involved, have not yet been clarified. However, they are likely to be related to various signaling steps and physiological responses, since this molecule modulates the production of gibberellin in the plant. Thus, new studies must be carried out, since understanding this process can provide productivity increases in the near future.

\section{Conclusion}

In conclusion, trinexapac-ethyl in the doses of 30 and $60 \mathrm{~g}$ i.a. ha ${ }^{-1}$ has a positive effect on the initial growth of Eucalyptus urograndis, Clones I-144 and 1407.

Clone I-144 showed higher growth than Clone 1407, independently of the plant growth regulator application. However, Clone 1407 obtained proportionally more significant gains with the application of trinexapac-ethyl compared to Clone I-144.

\section{Acknowledgements}

The authors would like to thank all members of the Weed Sciences Laboratory (LAPDA) of Sao Paulo State University-UNESP/FCAV for the technical and financial support during the work.

\section{References}

Adams, R., Kerber, E., Pfister, K., \& Weiler, W. (1992). Studies on the action of the new growth retardant CGA $163^{\prime} 935$ (cimectacarb). Progress in Plant Growth Regulation, 13, 818-827. https://doi.org/10.1007/978-94011-2458-4_100

Belz, R. G., \& Cedergreen, N. (2010). Parthenin hormesis in plants depends on growth conditions. Environmental and Experimental Botany, 69, 293-301. https://doi.org/10.1016/j.envexpbot.2010.04.010

Belz, R. G., \& Duke, S. O. (2014). Herbicides and plant hormesis. Pest Management Science, 70, 698-707. http://dx.doi.org/10.1002/ps.3726

Calabrese, E. J., \& Baldwin, L. A. (2002). Defining hormesis. Human Experimental Toxicology, 21, 91-97. https://doi.org/10.1191/0960327102ht217oa 
Carvalho, L. B., Alves, P. L. C. A., \& Duke, S. O. (2013). Hormesis with glyphosate depends on coffee growth stage. Annals of the Brazilian Academy of Sciences, 85, 813-821. http://dx.doi.org/10.1590/S0001-3765201 3005000027

Cedergreen, N. (2008). Is the growth stimulation by low doses of glyphosate sustained over time? Environmental Pollution, 156, 1099-1104. https://doi.org/10.1016/j.envpol.2008.04.016

Cedergreen, N., Felby, C., Porter, J. R., \& Streibig, J. C. (2009). Chemical stress can increase crop yield. Field Crop Research, 114, 54-57. https://doi.org/10.1016/j.fcr.2009.07.003

Correia, N., \& Villela, G. B. (2015). Trinexapac-ethyl and sulfometuron-methyl selectivity to young eucalyptus plants. Planta Daninha, 33, 259-266. http://dx.doi.org/10.1590/0100-83582015000200011

Garau, A. M., Lemcoff, J. H., Ghersa, C. M., \& Beadle, C. L. (2008). Water stress tolerance in Eucalyptus globulus Labill. subsp. maidenii (F. Muell.) saplings induced by water restrictions imposed by weeds. Forest Ecology and Management, 255, 2811-2819. https://doi.org/10.1016/j.foreco.2008.01.054

Indústria Brasileira de Árvores (IBÁ). (2016). Relatório IBÁ 2016. Retrieved from http://iba.org/images/shared/ Biblioteca/IBA_RelatorioAnual2016_.pdf

McDonald, L., Morgan, T., \& Jackson, P. (2001). The effect of ripeners on the CCS of 47 sugarcane varieties in the burdekin. Proceedings-Australian Society of Sugar Cane Technologists, 23, 102-108.

Moddus. (2017). Bula. Retrieved from http://www.agricultura.pr.gov.br/arquivos/File/defis/DFI/Bulas/Outros/ MODDUS.pdf

Nakayama, K., Kamiya, Y., Kobayashi, M., Abe, H., \& Sakurai, A. (1990). Effects of a plant-growth regulator, prohexadione, on the biosynthesis of gibberellins in cell-free systems derived from immature seeds. Plant and Cell Physiology, 31, 1183-1190. https://doi.org/10.1093/oxfordjournals.pcp.a078033

Nambiar, E. K. S., \& Sands, R. (1993). Competition for water and nutrients in forests. Canadian Journal of Forest Research, 23, 1955-1968. https://doi.org/10.1139/x93-247

Nascimento, V., Arf, O., Silva, M. G., Binotti, F. F. S., Rodrigues, R. A. F., \& Alvarez, R. C. F. (2009). Uso do regulador de crescimento etil-trinexapac em arroz de terras altas. Bragantia, 68, 921-929. http://dx.doi.org/10.1590/S0006-87052009000400012

Pereira, F. C. M., Nepomuceno, M. P., Pires, R. N., Parreira, M. C., \& Alves, P. L. C. A. (2013). Response of eucalyptus (Eucalyptus urograndis) plants at different doses of glyphosate. Journal of Agricultural Science, 5(1), 66-74. https://doi.org/10.5539/jas.v5n1p66

Pires, R. N., Pereira, F. C. M., Nepomuceno, M. P., \& Alves, P. L. C. A. (2013). Effects of the simulated drift of ripeners on Eucalyptus urograndis. Journal of Agricultural Science, 5(12), 78-86. http://dx.doi.org/10.5539/ jas.v5n $12 \mathrm{p} 78$

Rademacher, W. (2000). Growth retardants: Effects on gibberellin biosynthesis and other metabolic pathways. Annual Review of Plant Physiology and Plant Molecular Biology, 51, 501-531. https://doi.org/10.1146/ annurev.arplant.51.1.501

Velini, E. D., Alves, E., Godoy, M. C., Meschede, D. K., Souza, R. T., \& Duke, S. O. (2008). Glyphosate applied at low doses can stimulate plant growth. Pest Management Science, 64, 489-496. https://doi.org/ $10.1002 /$ ps. 1562

\section{Copyrights}

Copyright for this article is retained by the author(s), with first publication rights granted to the journal.

This is an open-access article distributed under the terms and conditions of the Creative Commons Attribution license (http://creativecommons.org/licenses/by/4.0/). 